\title{
Geografía del desierto y turismo de la naturaleza. La revista En Viaje y la mirada sobre el paisaje nortino: 1945-1966 1
}

\author{
José Antonio González Pizarro²
}

\begin{abstract}
RESUMEN
El artículo analiza el cambio perceptual sobre el Norte Grande, desde la negación de la geografía del desierto como lugar de atracción turística en las guías de viajeros como en los manuales de geografía hasta el año 1948, cuando comenzó una lenta valoración del espacio nortino en la educación geográfica del sistema nacional como en la importante revista En Viaje, que editaba la Empresa de FF.CC. del Estado. Esto significó la incorporación de escritores nortinos en las colaboraciones de la revista y dar cuenta tanto del significado de la naturaleza del desierto desde la costa hasta la precordillera como del patrimonio arqueológico que se descubrirá en la década de 1950. Esta nueva mirada coincidirá con un fuerte regionalismo nortino -desde Arica hasta Antofagasta- como también de una preocupación del Estado por el desarrollo regional, que tendrá su mejores expresiones de divulgación turística en la década de 1960.
\end{abstract}

Palabras claves: Norte de Chile, Geografía, Patrimonio.

\begin{abstract}
This paper analyzes the change of perception about the Big North, from the negation of the geography as a tourist attraction in both traveler' guides and geography manuals until 1948, when a show appraisal of the northern space began in the geography instruction of the nacional educational system and also in the important journal En Viaje, edited by the National Railway Company. This involved incorporating northern writers in the journal and giving account of both the meaning of the desert nature from the coast to the pre-Andes and the archaeological patrimony that would be discovered in the 1950s. This new view will coincide with a strong northern regionalism - from Arica to Antofagasta - and also the country's concern about regional development, whose best tourist expression will be shown in the 1960s.
\end{abstract}

Key words: North of Chile, Geography, Patrimony.

1 Proyecto Fondecyt $\mathrm{N}^{\circ} 1095130$ y del proyecto NS100046 Núcleo Milenio de Ciencias Sociales, Ciencia regional y Políticas Públicas 2011. Artículo recibido el 3 de mayo del 2011, aceptado el 20 de enero de 2012 y corregido el 24 de enero de 2013.

2 Universidad Católica del Norte (Chile).

E-mail: jagonzal@ucn.cl 
En la geografía de Chile el espacio desértico que engloba al Norte Grande, Ilámese desierto de Atacama o pampa del Tamarugal, las regiones de Tarapacá y Antofagasta, fue $-y$ es- percibido de modo singular por el resto del país. Se le asocia a la potente industria salitrera, al surgimiento del proletariado y al ciclo de huelgas y masacres que definieron el periodo parlamentario o la república oligárquica. Esto en el nivel cognitivo de la historiografía. Empero, cuando se tiende a identificar sus elementos geofísicos, se pondera un espacio árido, seco, sin pluviosidad ni vegetación, haciéndose notar lo inhóspito y la dificultad de sus conexiones por la no existencia de poblados cercanos, salvo las concentraciones en cantones de oficinas salitreras hasta la crisis de la década de 1930 (González Pizarro, 2008: 23-46; 2009: $91-$ 116).

La vinculación del paisaje con el hombre también ha permitido reforzar algunos tópicos, que han apuntado a sentar determinados estereotipos humanos surgidos de esa relación ecológica entre el sujeto que habita en el desierto y la naturaleza agreste (Sabella, 1955; Moretic, 1962; Reyes, 1969; Bravo Elizondo, 1983; González Pizarro, 1983; Maya, 2005; Brunet, 2006). De igual modo, las modalidades de asentarse o establecer un estilo de vida adaptable a la adversidad climática, revelan culturas distintas no solamente en el tiempo sino en sus hábitats geográficos, (Núñez, 1992; Garcés, 1999; González, 2002; González Pizarro, 2003; Arce, 2004; Panadés y González Pizarro, 1998; Bravo Elizondo y González Miranda, 1994; Galdames, 1981; Urzúa, 1957).

No obstante, el territorio fue recorrido por diversos hombres de ciencias, principalmente ingenieros de minas y geólogos, científicos y exploradores tanto chilenos como extranjeros, en razón de conocer el espacio, catastrar los recursos mineralógicos, levantar mapas o realizar cateos para la industria salitrera durante el siglo XIX (González, 2007; González Pizarro, 2009).

Queremos centrar nuestra atención en el tránsito del espacio geográfico del Norte Grande, como "frontera turística" para el país, hacia el desvelamiento de la existencia de un "paisaje holístico", en cuanto a ser asumido en su totalidad, que encerraba tanto un paisaje natural y un paisaje cultural, donde de modo dialéctico la acción antrópica comenzó a diseñar no solo una fisonomía en la región nortina sino una visión que va a pasar desde un ángulo explicativo, centrado principalmente en lo inhóspito del ambiente y el reduccionismo antropológico de las poblaciones precordilleranas, hacia uno comprensivo, que va a conjugar una nueva mirada que detecta el valor de la naturaleza del desierto -en concordancia con la óptica turística de lo exótico- con el rescate y valoración de lo patrimonial existente derivado de las etnias originarias, tanto atacameña como aymara. Seguidamente la revaloración de los centros urbanos costeros.

Esta última opción va a visualizarse nítidamente en la construcción de la imagen del Norte Grande por la revista En Viaje.

\section{De las fotografías y postales del ciclo salitrero a los manuales de geografía. La reversión por el interés del norte chileno}

Importa destacar que el territorio en cuestión también llamó la atención hacia comienzos del siglo XX al mundo científico europeo. En ese contexto, se pudo constatar la presencia de variadas misiones arqueológicas, principalmente francesas y alemanas, sobresaliendo Eric Boman y Max Uhle (González Pizarro, 2010a; Boman, 1908; Núñez, 2010; Santoro et al., 2010). Desde ese tiempo el territorio del norte de Chile, en especial el desierto de Atacama, ganó fama como el espacio más seco y árido del mundo.

También es dable acotar la importante imagen que proyectaron en Europa y en los EE.UU., las diversas postales de oficinas salitreras, muelles y puertos nortinos, vistas de centros urbanos de Taltal hasta Arica, que reforzaron el coraje de habitar en la franja o en la depresión intermedia del espacio desértico nortino (Silva, 1892-1919; Valenzuela, 1927; Burgos, 2003, 2005; Álvarez, 1980; González y Pereira, 1995; Vásquez, 1997, 2002; Andrade, 2008; Recabarren et al., 1979; Cordero, 2010) y, a la vez, exhibieron lo complejo de 
la habitabilidad en un territorio adverso a la presencia humana. El hombre dotó de significación a determinados lugares que fueron testimonios de su presencia en el gran espacio del Norte Grande.

El tópico geográfico del espacio nortino para el chileno alejado de estas latitudes fue lo inhóspito, establecido como sinonimia del desierto. Si se revisan las descripciones en los manuales de geografía en el periodo 19481968, nos encontramos con una imagen que se ajusta a lo descrito por viajeros y a lo que la climatología señalaba: era difícil para los chilenos del centro y sur del país recrear una vida desprovista de los elementos básicos de la actividad agropecuaria o de una naturaleza feraz y verde. Esto es lo que se aprecia en los textos que moldearon las percepciones de niños y jóvenes nacionales, redactados por varios autores, agravándose en el periodo en estudio que los niños de instrucción primaria tuvieran solamente dos textos antiguos para informarse de nuestra geografía, el de Luis Bustos Pérez y principalmente el de Luis Pérez Pérez (Pérez, 1931-1958), Elementos de geografía: nociones de la geografía de Chile y de América con varias ediciones. Elías Almeyda Arroyo, con su Geografía de Chile, que vio luz en 1932 hasta la última edición revisada por el autor, la de 1955 (Almeyda, 1955), fue un intento de ampliar la información que reforzó la distancia perceptual entre el centro-sur de Chile y el norte. En menor escala puede observarse en Oscar Kaplan C., Geografía de Chile, impresa por el Instituto Geográfico Militar en 1948 con 620 páginas, y su nueva edición en 1954 Nueva Geografía de Chile: de acuerdo con los programas aprobados por el Ministerio de Educación, que prestó una atención desusada a la puna de Atacama (Kaplan, 1970: 19, 61, 69-74). El volumen de Francisco Frías Valenzuela, Manual de Geografía de Chile (Frías Valenzuela, 1960-1966), se ajusta a una descripción que no alimenta la imaginación juvenil. E incluso su Geografía General. Educación Media. De acuerdo con la reforma educacional, destina solo una página al desierto del norte de Chile (Frías Valenzuela, 1970: 176).

La aparición de la obra de Pedro Cunill, Geografía de Chile: nuevo texto para la enseñanza secundaria, bajo los auspicios de la Imprenta Universitaria en 1963, vino a señalar un giro en la "mirada" sobre el paisaje nortino, como era la finalidad del libro: "Nuestro deseo es mostrar la acción del grupo humano chileno creando y transformando el paisaje geográfico" (Cunil,1963: Introducción). De esta manera, conjugando la lección, lecturas, ejercicios prácticos y salidas a terreno, mostró en lo que nos interesa subrayar la importancia del espacio transformado en un "paisaje holístico", la formación de una economía tanto minera como pesquera y, por cierto, los lugares mineros y urbanos con sugerencias de visitas. Es el sujeto humano, en los pueblos indígenas de atacameños y changos, los que abrieron su habitabilidad en las alturas cordilleranas y en las orillas del océano Pacífico, en el pretérito precolombino, o los cateadores del siglo XIX en la depresión intermedia y las urbes costeras, domeñando la geografía del desierto, lo que resalta Cunill. En la selección de lecturas, trajo a colación los estudios de hombres como Max Uhle, Ricardo E. Latcham, y mujeres como Grete Mostny, para desvelar el pasado prehispánico, mientras autores como Andrés Sabella, Gabriela Mistral y David Rojas González refieren del significado de la pampa para los poetas y personas nortinas, o que habían vivido en Antofagasta, como el caso de la Mistral. Hay un acercamiento comprensivo que se transmite hacia el lector de los campamentos mineros salitreros de Victoria (Tarapacá), María Elena, Mantos Blanco, Chuquicamata o la ciudad de Antofagasta (Cunill, 1963: 12, 25, 31, 55, 56, 60-63, 91, 134, 143, 175-185,198-205).

La circulación del libro de Cunill, con una nueva edición en 1965, coincidió con una mayor y mejor producción de mapas y atlas de Chile confeccionados por el Instituto Geográfico Militar (IGM) en los años 19651968 (Kaplan, 1970: 7). Ya en 1955 el IGM había renovado el registro de la mapoteca nacional, cuya última información databa de 1911 (Flores Silva, 1958: 59). Además, coincidió con una inflexión en la historiografía nacional, por la historia social en la década de 1950, con los volúmenes de Julio César Jobet y Hernán Ramírez Necochea, en 1951 (Pinto, 2007:5). Y esta se encontraba en el norte salitrero.

Por consiguiente, la zona norte del país no motivó un atractivo para el chileno hasta 
fines de los años 40. Fueron los extranjeros, los que se atrevieron a llegar a sitios recónditos. El paraje les atrajo y lo hallado, desde vestigios monumentales y poblaciones aisladas de raíz indígena, atacameña o aymara, fueron motivos para hablar del espacio y sus señales culturales.

El cierre del ciclo salitrero y el despoblamiento de decenas de oficinas salitreras en ambas provincias produjeron un panorama desolador en el paisaje nortino. A la sensación de abandono -los denominados "pueblos fantasmas"- se unieron los cuadros de la cesantía, el hambre y la pérdida de horizontes para los pueblos intermedios, donde Pampa Unión va a desaparecer en la primera mitad de la década de 1950 (González Pizarro, 2011).

El devenir del ciclo cuprero en la región de Antofagasta, con la instalación de los capitales norteamericanos en Chuquicamata, en 1912, y el arribo de los ingenieros de esa nacionalidad, fue de una importancia significativa. Fueron norteamericanos los que se interesaron por la precordillera, abriendo senderos con sus vehículos motorizados. Aquello en nuestra opinión fue un primer hito hacia el nuevo "rescate" del paisaje desértico. Uno de ellos, Earl Hanson, Ilamó la atención sobre las localidades de Toconce, Aiquina y Caspana, las denominadas por F.C. Walco$\mathrm{tt}$, "out-of-the-world" villages", por la vida apacible, sin disturbios en su cotidianeidad, con sus fiestas patronales y sus iglesias, que el párroco, residente en Chiu-Chiu, visitaba tres veces al año. Hanson anotó que cerca de las Vega de Turi, "lie the ruins of an old city of copper workers, in which the Spaniards had evidently built a few adobe houses. What do these ruins mean to the present population? Absolutely nothing, as far as I could find out" (Hanson, 1926: 376) .

Un segundo hito fue la decisión del Estado de ampliar las redes ferroviarias. Decidió unir el ferrocarril fiscal desde Pueblo Hundido, en la provincia de Copiapó, hasta Pintados en la de Tarapacá: fue el conocido Longitudinal Norte, inaugurado el 10 de enero de 1919 (Thomson, 2003), aunque la explotación definitiva del recorrido entre Iquique y Calera comenzó el 19 de marzo de 1930 (En
Viaje, 1960: № 325)33. Más tarde, construir el ferrocarril de Antofagasta a Salta, en 1922, cuyos estudios se remontaban hacia 1906. La vía se inauguraría en 1948, lo cual posibilitó un nexo que mostró la pampa y la cordillera andina, abriendo otra posibilidad de visualizar los Andes desde un tránsito desde el Pacífico (González Pizarro, 2002; Benedetti, 2005). Para 1949 la frecuencia del FF.CC. de Antofagasta a Salta y viceversa era semanal, demorando dos días el trayecto: salía el tren con coche y comedor el día domingo desde Antofagasta y llegaba a Salta el martes.

Para algunos, la vía férrea iba a llevar "la antorcha del progreso, de la cultura, el conocimiento mutuo" (Szigethy, 1948); para otros, Antofagasta se convertía en terminal de los ferrocarriles internacionales (Jofré, 1966).

El Longitudinal Norte estuvo en combinación con los trenes de Santiago y Valparaíso y mantuvo una serie de estaciones que desde Pueblo Hundido abarcó Altamira, Catalina, Aguas Blancas, Baquedano, Antofagasta, Calama, Pedro de Valdivia, Miraje, Chacance, Empresa (Toco), Teresa, Pintados e Iquique, lo cual privilegió la provincia de Antofagasta y la ciudad de Iquique. Hacia 1966, el tramo desde Calera a Iquique, tenía salidas los días domingo (con combinación a y de Antofagasta) con coches de primera, segunda clase y comedor, el más completo; los jueves en Baquedano combinaba hacia Calama, los coches de segunda clase y buffet; los sábado, el tren Ilegaba hasta Antofagasta, con el mismo rango de coches de los jueves; los martes había un tren, con coches de segunda clase y buffet que llegaba hasta el Toco. El tramo de Iquique a Calera salía los lunes y jueves; los de Antofagasta y el Toco, los martes y sábado (En Viaje, 1966, №388).

Un tercer hito fue la necesidad de replantear la estrategia económica en el norte, apuntando a las posibilidades turísticas. El Memorial de la Comisión del Norte de 1933, planteó que dentro del $25 \%$ de las utilidades de la venta de salitre y yodo, debía destinarse

\footnotetext{
3 "Ferrocarriles vencedores del desierto y la montaña", En Viaje, noviembre de 1960, № 325. La referencia a la revista cuando no figura un autor, se indicará con el número de ella.
} 
un " $1 / 3$ para proveer el descanso anual de empleados y obreros, sea financiando viajes o estableciendo en la zona agrícola de la región, hoteles de descanso" (Memorial, 1933:17). Si bien la solución salitrera fue la que estableció la COVENSA, en 1934, la idea de articular hoteles en el norte quedó en la ciudadanía.

Los gobiernos radicales que sucedieron entre 1938-1952 retomaron la idea de la construcción de hoteles, por medio de la Honsa, Hotelera Nacional Sociedad Anónima. De esta manera, Antofagasta pudo remodelar su borde costero con la instalación del Hotel Turismo, construido entre 1950-1953 (Galeno, 2008: 38-43), que junto con el edificio Pabellón de Turismo, de 1939, vino a simbolizar la importancia que se le asignaba al turismo regional, máxime cuando en 1952 quedó totalmente construido el puerto fiscal de Antofagasta, que estructuró una nueva relación ecológica entre los habitantes de la urbe y el mar (González Pizarro, 2010b: 9-27). En Arica, la Junta de Adelanto, establecida el 24 de septiembre de 1958, rápidamente posicionó a la ciudad como un importante centro turístico, con la habilitación de la playa Lisera, la construcción del Casino municipal, la Hostería del valle de Codpa, entre otras obras fundamentales (Díaz Araya et al., 2010). A su vez, en Iquique la atención se dirigió en seguir aprovechando la playa Cavancha y su infraestructura hotelera, además de procurar su conexión con la ciudad boliviana de Oruro, para la construcción de un camino carretero, que encontró acogida en el gobierno de La Paz, que apoyó dicha iniciativa por ley 5 de enero de 1950.

Anotemos que para 1966 la Organización Nacional Hotelera S.A., contaba con tres hoteles en el Norte Grande: "El Paso" en Arica, "Prat" en Iquique y Hostería "Pica".

Habrá que consignar la preocupación por el norte, evidenciado en los estudios planteados en la década de 1960 por la Corporación de Fomento hacia la pampa del Tamarugal, las ideas del Plan Andino de mediados de la década de 1960, y las iniciativas de Ximena Aranda sobre un plan de desarrollo local en San Pedro de Atacama (Aranda et al., 1964).

\section{EI FF.CC longitudinal norte y la revista En Viaje. Las posibilidades turísticas al norte chileno}

El norte chileno nunca fue justipreciado por su paisaje. El desierto era el contrapunto a diferenciar del centro y sur del país. No mereció elogios aun cuando gran parte de la riqueza nacional proviniera de su territorio. $Y$ esto fue una constante en los textos de mayor divulgación, con características de ofrecer un cuadro del país. Así lo tenemos en el famoso Manual del viajero. Baedeker de la República, de 1910, que del norte destaca a Iquique, ponderando el paseo de Cavancha (Manual, 1910: 3, 129). No le fue a la zaga las noticias de Impresiones de la República de Chile en el siglo XX, de 1915, donde se lee: "Las dos grandes ciudades salitreras, Antofagasta e Iquique, son los únicos centros de esta región que se pueden Ilamar habitables; ambas tienen muchas características en común y ambas carecen de vegetación. Las dos cuentan con ferrocarril y son puertos de suma importancia comercial" (Impresiones, 1915: 445-446).

En 1927 se creó la sección de turismo en el Ministerio de Fomento y la Empresa de FF.CC. del Estado en 1934 comenzó a publicar la Guía del Veraneante, la que apuntó a poner de relieve el paisaje meridional de Chile (Booth, 2008) en desmedro del septentrión hasta avanzada la década de 1940. El ocultamiento del "desierto de Atacama y el altiplano en el norte de Chile" fue por semejarse a Perú y Bolivia, "que no eran considerados en Chile como un modelo estético" en la intención de vincular el paisaje sureño con los lugares del hemisferio norte, principalmente Suiza (Booth, 2010: 17). Booth (2008) refiere que entre 1938-1962 la Guía del Veraneante registró solamente un $4,7 \%$ del total de sitios atractivos del país en la zona norte de Chile.

La propia Guía del Veraneante de 19391940 refería que "entre las provincias de Tarapacá y Coquimbo... por no existir las comodidades que exige el viajero moderno en materia de hoteles y transportes, nos vemos obligados a excluir" (Booth, 2010: 20). 
La reacción regional ante el ocultamiento de su paisaje supuso que la Guía Oficial de la Exposición y Feria de Industria, Arte y Comercio, editada en Antofagasta en 1934, diera cuenta de la urgencia de noticiar "en forma amplia las playas incomparables bellas y el maravilloso clima que gozamos, para iniciar la corriente de turismo y desmentir erradas apreciaciones que se tienen sobre el clima del norte". Pero no solamente eran las playas sino que también podían mencionarse lugares de interés turístico, tanto natural como históricos (Guía Oficial, 1934:5,13-21). La Guía San Luis para la provincia de Antofagasta, de 1945, fue de circulación aun más restringida que la de 1934 y los datos se repetían. En Iquique, el esfuerzo mayor fue El pequeño Cicerone. Guía administrativa, comercial, industrial y profesional de Iquique, editada por la Imprenta La Joya, en 1936, que consignó poquísimos datos sobre lo que estamos tratando.

En 1940, Benjamín Subercaseaux dio a conocer su Chile o una loca geografía, Ilamando la atención hacia la conformación geográfica del país. El norte quedó plasmado de modo pendular, entre la toponimia que consignaba su espacio - "los nombres geográficos señalan el pensamiento y las etapas del esfuerzo en la lucha por la vida", evidenciado en Pampa engañadora o Aguas Blancas, y el realismo de su cotidianeidad social- "los 'campamentos' como grandes conventillos con un patio inmenso: la Pampa" (Subercaseaux, 1949: 99-101;). A esta la siguió, una obra tan intensa en imágenes de fuerte sentido lírico, como Norte Grande, de Andrés Sabella, en 1944, que dejó indeleble no solamente la epopeya humana en el territorio sino su imagen inicial: "Pampa abierta... No es posible que nada se esconda a los ojos de la muerte. Por los suelos se ven los rastros del más duro tiempo..." (Sabella, 1944:19-21).

Importa señalar que el tránsito desde la geografía del desierto hacia el paisaje nortino significó tanto visualizar nuevas relaciones entre el hombre y la naturaleza como enfocar el paso del hombre por la geografía dejando testimonios de su señorío, o sea, transformando el espacio natural en una espacio culturizado. No había que reparar tanto en las dificultades, en la adversidad geofísica del espacio del desierto, sino en lo que ofrecía de interés, de encanto como paisaje tanto cultural como ignoto que encerraba una belleza virgen, al menos para los ojos no indígenas.

Para entender esta inflexión en torno al paisaje nortino, no es posible disociar su asociación a un prototipo humano que la historia y la literatura, esta última vinculada a la generación del 38, va a poner de relieve: el proletariado minero. En este tipo social, representativo de la clase trabajadora, se va a entender la nueva ciudadanía que va asumiendo un protagonismo sociopolítico. Y esto nos remite a la discusión en torno a la nación y su identidad que, a partir de la institucionalidad de 1925, en una forma "republicana, democrática y social" característica de esta denominada "Cuarta República" (Cristi y Ruiz-Tagle, 2006: 114-125), tiende a ampliar la ciudadanía, por ejemplo el segmento de las mujeres, ensanchando el "imaginario social nacional" (Rojas, 2006), con la incorporación de nuevos sujetos -a los que le asigna derechos sociales- que dentro del mundo popular exhiben sus diferencias productivas (Salazar y Pinto, 1999: I) y de paisajes: el huaso del sur, el pampino del norte, el obrero industrial urbano. Sabella como Nicomedes Guzmán se hicieron cargo -de esta ampliación genérica del "roto chileno"- que significan estos nuevos componentes sociales de la nación, ahora, visibles y legitimados (Guzmán, 1966; González Pizarro, 2007). Empero, no logran resquebrajar en la época de estudio, el binomio Estado-Nación (Góngora, 2006) y la "homogeneidad racial". El Estado, en este marco, prosigue lo heredado desde el siglo XIX planteando los componentes identitarios en términos canónicos lo que los textos y manuales de enseñanza van a reproducir (González Pizarro, 1996; Larraín, 2001; Cid y San Francisco, 2009: I-II). Cabe puntualizar que la atención hacia las etnias nortinas que van vinculadas con los espacios precordilleranos, va a ocurrir inicialmente en el plano académico. Recién en el Congreso Nacional de Arqueología de Arica, 1960, y en el fundamental Congreso Internacional de Arqueología, verificado en San Pedro de Atacama, de 1963, el pasado prehispánico y los pueblos indígenas de Tarapacá y Antofagasta, comienzan a poblar el "imaginario nacional" con el espacio geográfico nortino, más allá de las influencias de Tiawanaku o del Impero Incario. Empero no logra ser asumido en la 
época dentro de la "diferencia" en el componente de la nación. No hubo un efecto, como se percibe en Bolivia o Perú, de procurar la legitimación de la heterogeneidad racial que va a dar sustento a la propuesta etnohistórica de Anderson Smith, precisamente en esa asociación entre indigenismo y nacionalismo (Smith, 1990; 2004). Tenuemente hacia las postrimerías del periodo en estudio emerge una vinculación entre las poblaciones indígenas y la música andina, como componente folclórico nortino.

Habrá que considerar, la tardía incorporación del norte a la soberanía chilena, después de la guerra del Pacífico (1879-1883), y las diferencias habidas en la estructuración político-administrativa, industria salitrera, proceso de "chilenización" más fuerte en Tarapacá -territorio anexionado- que en Antofagasta -territorio reivindicado- para poder comprender la "mirada" del centro y sur del país sobre esta geografía (González Pizarro, 2010c).

En este marco, el Norte Grande va a ser leído como paisaje nortino y con ello incorporado al itinerario del turismo nacional. De este modo, en sintonía con la literatura salitrera de la generación de 1938 y la nueva historiografía social, de raíz marxista, que rescata la épica proletaria, va a incorporarse a la identidad nacional, aportando otra diversidad del paisaje criollo (Canihuante, 2005: 75-92). Y, tal como ha acontecido en otros espacios, donde el turismo ha replanteado y modificado el paisaje, el norte chileno va a posibilitar desde fines de la década de 1950 y comienzos de los años 60 una relación de interdependencia entre el territorio, el medio ambiente y el turismo (Vera, 1997). En esta perspectiva, el norte exhibe un crisol de paisajes o áreas de interés turístico que se desplegarán, a medida que se den cita los cuatro factores del sistema turístico: qué clase de turistas vienen hacia el norte, qué elementos públicos y privados hacen posible esta "oferta turística", qué medios de transporte y conectividad existen en las provincias nortinas y por último el destino turístico que tiene en consideración la "imagen" o atracción turística del paisaje que se difunde y si la sociedad local está internalizada al efecto. La fuente de información empleada no permite plantear el desenvolvimiento de cada uno de ellos, pero sí inferir que estamos ante un turista que puede hacer un turismo intrarregional como extrarregional en diversas clases de vagones, desde el más popular hasta de primera clase, desde la premisa que es el FF.CC. del Estado el que facilita al turista la accesibilidad tanto hacia la costa como al interior del Norte Grande, teniendo como límite la estación de Pintados en Tarapacá, lo cual excluye a Arica. Fue la carretera Panamericana la que va a favorecer a la ciudad de Arica. Los elementos públicos están representados por la importancia que el Estado y los municipios asignan a la actividad turística, desde infraestructura hotelera, transporte, informaciones hasta sugerencias de parajes y lugares naturales como culturales. La ampliación de caminos asfaltados en la década del 60 hacia el interior de la provincia, en el caso de Antofagasta, abrirán la accesibilidad hacia las localidades del interior precordillerano, mientras la carretera Panamericana acercará las oficinas salitreras paralizadas y en funciones. En este impulso, la Cámara de Comercio, junto a las entidades como la Junta de Arica o el Centro para el Progreso de Iquique, de Antofagasta o de Mejillones, han permeabilizado a las sociedades locales sobre la importancia del turismo para el progreso económico y social.

Es importante indicar que el acento, a partir de 1962, sobre el espacio nortino dice relación también con un énfasis sobre el territorio nacional, máxime cuando se han roto las relaciones diplomáticas con Bolivia.

Es dable consignar que la geografía del desierto encerraba las potencialidades de constituirse en un paisaje nortino para el forastero o el turista. En este acercamiento, la necesidad de ruptura para desvelar la segunda noción hizo necesaria entender en el paisaje un "sistema de relaciones geográficas" compuesto tanto de un fenosistema (elementos perceptibles del paisaje) como de un criptosistema (factores ocultos que explican los elementos del paisaje)" (Gómez, 2000: 447). Y ello obligaba a una aproximación de construir socialmente otra imagen del espacio. Una que pudiera ofrecer "escenarios" para el turismo constituidos por una gama de insumos, desde contemplar la cultura local y costumbres, pasando por el patrimonio monumental hasta las vías de acceso para ver el paisaje natural (Miranda Román, 2006: 
201-211). No escapó a esta nueva percepción, asociar el silencio de las oquedades del páramo a una oferta del "consumo del paisaje" para el turista -principalmente extranjero- de "estar solo" ante la naturaleza o las ruinas monumentales precordilleras. En tal sentido, la mirada y las fotografías de Roberto Montandón, un arquitecto suizo, apuntan a "orientar" al turista, cual peregrino, qué visualizar como "escenario" (Lagunas, 2006: 120). En esa tensión radicará lo "auténtico", lo original, ante la "desrealidad de lo real" como edificación de la artificialidad, que va a afectar en el tiempo a las localidades precordilleranas. De esta manera, habrá diversas clases de turistas como miradas, como ha sugerido John Urry (2004; 2008), desde el individuo a la masificación, desde la percepción romántica a la colectiva; y, a la vez, una reflexividad turística, que apuntará a institucionalizar los estudios al respecto que, en el caso que nos interesa, abrirá un abanico en la revista En Viaje, desde artículos referidos al paisaje cultural y natural, procedentes de plumas nortinas, hasta números monográficos de la publicación sobre Antofagasta, Iquique, por ejemplo, claramente identificatorios como atractivos turísticos. Así, se va a producir una disonancia perceptual en cuanto al Norte Grande, entre las disciplinas que lo han asumido -la literatura e historiografía que hemos hecho referencia- y el incremento de la reflexividad turística que propaga En Viaje. Importa más la monumentalidad patrimonial y los escenarios naturales que los hitos y lugares de masacres del proletariado pampino. Como advirtiera en la década de 1930 el alemán A. Glücksmann, el turismo afectaba las imágenes externas de los lugares (Gómez, 1987). Era necesario omitir en el paisaje los lugares de conflictos y tender hacia los lugares de recreación y de ocio. Así, la totalidad del espacio geográfico también se veía mutilado en su dimensión simbólica para el lugareño como para el turista. Empero, es posible atisbar en lo devenido entre las décadas de 1950 y 1960 un cambio en la forma de presentar el "paisaje nortino" en la revista En Viaje. Se puede conjeturar que en la década de 1950 el hinterland de Antofagasta como Iquique, a pesar de los impactos sobre la naturaleza por el hombre urbano -principalmente ligado a las faenas mineras-, este todavía podía exhibir cierta autenticidad como tal, había parajes todavía desconocidos para la muchedumbre turística como monumentos que todavía conservaban las huellas del deterioro de los años; para la década de 1960 hay una orientación de transformar el paraje en "escenarios" con vista a lo que se ha denominado la "acción turística". Si en la década de 1950 el turista individual o de pequeños grupos podía contemplar en tales parajes dimensiones utópicas, o posiblemente eutópicas, o sea, asignar a las etnias originarias y sus localidades como "lugares buenos" donde todavía podía hallarse cierta felicidad (Hiernaux-Nicolàs, 2002: 16); en el decenio siguiente, la propia conectividad vial con el desarrollo de las industrias locales -cerámicas (los moldes en serie de las iglesias de Chiuchiu, Toconce San Pedro de Atacama)-, textiles (vestimentas de lana de diversos auquénidos con vista al mercado turístico local) -y la creación de museos, el más notable el del P. Le Paige, en San Pedro de Atacama- provocó no solamente la asiduidad de visitantes, lo colectivo, donde se verificarán dos fenómenos interesantes: ofrecer al turista lo que él buscaba, lo que deseaba ver, de acuerdo a las informaciones turísticas (Augè, 1998:11) y a la par dar inicio a lo que John Urry va a denominar la cultura móvil, es decir, los souvenirs a que hemos aludido y ciertos registros en los basurales de las oficinas salitreras abandonadas $y$, más peligrosamente, los huaqueros, depredadores de los lugares sagrados indígenas.

La revista En Viaje creada por la Empresa de Ferrocarriles del Estado, en noviembre de 1933, a partir de 1940 se transformó en una publicación de información turística de alta calidad y de las mejores del continente, siendo difundida en las estaciones ferroviarias en quioscos y por el Ministerio de Relaciones Exteriores. El inicio de las informaciones más relevantes sobre el Norte Grande coincidió con la dirección de Manuel Jofré, en 1953.

Nuestras informaciones de la revista En Viaje (1933-1973) provienen de la digitalización que se encuentra en el website de Memoria Chilena de la Biblioteca Nacional. 


\section{En Viaje y el desvelamiento del paisaje nortino en la década de 1950. La visión premonitoria de Roberto Montandon}

El norte chileno fue incorporado a la planificación turística estatal en el encuadre de un mayor acceso de la población a las actividades recreativas. Esa política descansó en el papel de los FF.CC. y en la difusión de los paisajes por parte de una revista vinculada a los ferrocarriles estatales: En Viaje. De esta manera es posible encontrar una réplica en Chile de iniciativas extranjeras para promocionar el turismo y señalar someramente determinadas coincidencias, en cuanto a tres aspectos que se aprecian en la publicitación turística del territorio del norte de Chile. 1. La relevancia del FF.CC. en la conectividad del territorio nacional, 2. La inclusión de áreas geográficas que no eran atractivas, en cuanto a bellezas naturales de nota, para el turista extranjero y 3. La articulación de un grupo de escritores que establecerán, en base de la historia, leyendas nortinas, la legitimidad de ser parte de la identidad nacional.

El ferrocarril ha sido considerado fundamental en la etapa de la fase de "masificación" del turismo interno. Marguerite Sheffer (Sheffer, 2001), ha puesto de relieve cómo determinadas acciones en los EE.UU. -como la Federal Aid Road Act (1916) y la Federal Highway Act (1921) - contribuyeron a un plan de desarrollo ferroviario a través del país que dio cuenta de su territorio occidental, haciéndolo accesible a los segmentos no elitarios de la nación. Así, el FF.CC. abrió a los sectores no pudientes la posibilidad de realizar viajes turísticos mientras la elite lo realizaba por medio del automóvil. Este turismo tanto individual como colectivo produjo un efecto cívico estrechando la asociación entre el conocimiento geográfico y la identidad nacional. Este mismo fenómeno, entre turismo e identidad nacional, es posible observarlo en la Argentina de la postguerra de 1914 y más tarde en la de 1945. De acuerdo con el historiador Eugenio Scarzarella, la vinculación de las bellezas naturales con la idea de nación en el siglo XX pasa en la primera década desde una asociación entre nacionalismo y naturaleza, como una "encarnación simbólica de la patria para ofrecerla al culto cívico"; le sigue una etapa de entreguerras donde la naturaleza se vincula con la fuente de riqueza económica y una fase de postguerra mundial que hace de la naturaleza un "lugar de entretenimiento y disfrute popular, volviéndola accesible a toda la ciudadanía" (Scarzarella, 2002:6). De esta manera, la búsqueda de integración geográfica para fines turístico que observamos en el norte chileno es coincidente con el propósito que se observa en Argentina concerniente al territorio del Chaco, "un desierto ignoto"(Lois, 2002), poniéndose el énfasis entonces en el trabajo humano que logra modificar su naturaleza con la cosecha del algodón (Troncoso-Lois, 2004), o la incorporación de las tierras pampeanas y de la Patagonia, estimadas como "tierra radicalmente desconocida y vacía" (Navarro, 2001: 139-152; Navarro, 2005), hasta convertirse, mediante la creación de los parques nacionales, en un paisaje anejo al proyecto turístico de las ciudades sureñas de Argentina, como ser la vinculación del Parque Nacional Nahuil Huapi y el desarrollo de San Carlos de Bariloche (Navarro-Vejsberg, 2009: 414-433; Núñez-Vejsberg, 2010; Scarzarella, 2002: 5-72).

El conocimiento de los nuevos espacios de la geografía nacional, para el esparcimiento popular, discurrió bajo la forma de un plan comunicacional bien diseñado. En los EE.UU. bajo el eslogan "See America First" se acomodaron, como refiere Sheffer, las guías turísticas, los publicistas y estrategias modernas de marketing que, en el caso de los norteamericanos cada Estado tuvo un equipo que asumió esta labor. Como ha puntualizado Susan Schulter, "between 1936 and 1941, the Federal Writer's Project FWP produced comprehensive guides" (Schulter, 2005: 49-70), aportando cada guía a un panorama social, cultural e histórico de la nación entera.

En la Argentina de Perón, bajo el eslogan "Conocer la patria no es un derecho, sino un deber", se pudieron conjugar varios objetivos en una política socioturística, a saber, un mecanismo de patrimonialización de ciertos recursos naturales mediante la erección de parques nacionales, una intervención del Estado en la consolidación de las fronteras y la emergencia de un nuevo sujeto social, el obrero, como "modelo de la nueva ciu- 
dadanía" (Núñez-Vejsboeg, 2010; Scarzarella, 1998, Silvestre, 1999; Piglia, 2009). A la exclusividad social de ciertos lugares -el balneario de Mar del Plata- el peronismo reaccionó con su turismo popular (Scarzarella, 1998) difundiendo la nueva geografía turística a través de la publicación Visión de Argentina, en 1950 (Troncoso-Lois, 2004). En Uruguay, la política turística giró en torno al aprovechamiento de los balnearios y la construcción de los hoteles municipales, para atraer la masificación del ocio y la recreación (Da Cunha, 2005). (Da Cunha, 2010; Da Cunha y Campodónico, 2005).

En este contexto comparativo, podemos insertar la labor llevada a cabo por En Viaje, con un cuerpo de colaboradores que dieron noticia de lugares, con sus tradiciones y costumbres, de historia tanto colonial como actual, que encerraba el norte chileno, mientras el FF.CC. se constituía en el transporte popular para recorrer Chile en afanes de recreación y turismo.

En el transcurso de 1945 Roberto Montandon reveló en las páginas de la revista En Viaje sus primeras impresiones de un recorrido que abarcará de modo persistente hasta 1950. Anotó:

"El viajero que recorre rutas conocidas o se adentra hacia la cordillera en la región norte de Chile, se detiene ante reliquias y sitios históricos que despiertan su curiosidad a la vez que su sensibilidad. Puertas abiertas sobre el pasado, el estado emotivo que procura el allí asomarse tiene orígenes diferentes. Es la muda presencia de las masas de adobes tiahuanacosatacameños, calcinados por el sol del desierto. Es, en los oasis de la "Pampa desconocida", la humildad de aquellas pequeñas iglesias, genuino producto de ese arte rústico colonial. Paralelo $22^{\circ} 30^{\prime}$ : dos lugares perdidos en el valle del río salado, tributario del Loa: Aiquina y Caspana. Al borde de veredas rocosas talladas por la naturaleza, se levantan extrañas habitaciones de piedra, defendidas por sí solas en sus alturas inaccesibles... el Pucará de Lasana, un pueblo de importancia y a la vez que fortaleza... las casas tienen puertas y ventanas, las primeras que se señalan en la arquitectura americana...
Una carretera une Calama a Chiu-Chiu, pueblo somnoliento que recibe por los cuatro costados los vientos del desierto; la construcción de su deliciosa y vieja iglesia remonta al año 1557" (Montandon, 1945, №139).

La aproximación y el lenguaje descriptivo al entorno natural y a los lugares históricos, no solamente encierra una empatía con lo observado sino que transmite al lector palabras claves: la curiosidad de apreciar dicho patrimonio sin igual en el territorio y la sensibilidad hacia el paisaje natural, el sol, el terral del páramo, los oasis y las construcciones de culturas prehispánicas: todo esto es la pampa desconocida.

El impacto de lo contemplado en los viIlorrios precordilleranos condujo a Montandon a dedicarle una serie de artículos donde exaltó la naturaleza del desierto siempre con relación íntima con el hombre, como cuando describe el paso de Pedro de Valdivia por la comarca (Montandon, 1948: $N^{\circ} 175$ ).

Un acercamiento con acento "turístico" es el que se desprende de sus anotaciones de pueblos como Aiquina, Toconce y Turi, que alcanza a Chiuchiu, haciendo notar la ventaja de un buen vehículo, en este caso "un jeep" (Montandon, 1948: № 178).

Se maravilla ante el pucara de Lasana y se lamenta que lo apreciado por los viajeros del siglo XIX sobre "una muralla de circunvalación, hoy en día desaparecida" (Montandon, 1948: No 179).

Pero Montandon, también enfiló sus pasos hacia los asientos urbanos. Repara que Calama ha podido trocar su condición de antiguo pueblo indígena en una importante función de encrucijada estratégica con su red caminera y su ferrocarril internacional. Tocopilla le encanta su fisonomía arquitectónica como su ambiente, que lo asocia con puertos tanto antillanos como del Pacífico (Montandon, 1948: No 174).

Arica es a los ojos de Montandon, un lugar de conexiones internacionales, puerta de entrada a Chile: "Arica es un poema para quienes gustan pasar quince días sin hacer nada" (Montandon,1948, № 180). 
En septiembre de 1948 describe desde la lejanía la visión de San Pedro de Atacama:

"El desierto crece en proporciones inalcanzables y una luz diáfana, transparente, se desplaza vertiginosamente hasta iluminar a su paso la llanura huidiza, el borde de los desfiladeros y la cima de los cerros que, en planos sucesivos, escalonan sus alturas, hasta juntarse con el horizonte lejano... Lentamente, los novillos salteños, cachudos y sufridos, arrastran sus pezuñas herradas sobre el polvo blanquecino de las orillas del Gran Salar. En Iontananza, una delgada línea verde, pegada al pie de una pared de arenisca rojiza, renueva la visión lejana de los valles jugosos... El sol se ha perdido tras las cumbres... Rojo es el desierto, rojo el ganado y los jinetes envueltos en áureo polvo; roja está Atacama la Alta, sus techos, sus tapiales y el agua que corre por sus acequias rumorosas" (Montandon, 1948, № 179).

Pero no es solo comprender la naturaleza y las viejas estampas del arrieraje argentino; urge dar a conocer los vericuetos de senderos que unen a las localidades precordilleranas. Es el gran salar de Atacama lo que lo cautiva, lo hechiza en su totalidad. En su visión, aquello permitía recrear cuadro coloniales con la actualidad en dicho lugar (Montandon, 1948, $\left.N^{\circ} 181\right)$.

Una mirada romántica de la búsqueda de "algo" en el pasado, lo auténtico, la premodernidad, estrecha esa conjunción del paisaje construido por el hombre, una comunidad que requiere lo necesario.

Su incorporación al Consejo de Monumentos Nacionales, que desde el año 1948 va a contar con una "oficina permanente" de fiscalizar la aplicación de la ley, legitima el discurso de Montandon de exaltar los "múltiples intereses históricos y arqueológicos" habidos en el Norte Grande:

"El interés histórico-arqueológico de esta zona, se concentra en el notable ritmo arquitectónico de las primitivas iglesias españolas de Chiu-Chiu, San Pedro de Atacama y Toconao, en las ruinas de los pueblos atacameños de Lasana, San Pedro de Atacama, Aiquina y Turi, en los sorprendentes petroglifos del valle del río Salado y en el resultado de futuras excavaciones" (Montandon, 1948, № 182).

$Y$ todo esto era necesario difundir y preservarlo. Lo observado en el pueblo de Tarapacá, en la provincia homónima, donde las edificaciones coloniales yacen abandonadas y su población diezmada, conservando una historia de cuatro siglos, doctrina de indios, posta en el camino al Perú, constituyó un llamado de atención. Cada lugar escondía un patrimonio que era urgente hacer tomar conciencia a los habitantes y viajeros actuales (Montandon, 1949, N 191).

El afán de dar a conocer el patrimonio monumental de la precordillera andina, lo decide a redactar tres artículos al respecto, tomando como eje la evolución arquitectónica -que resaltó una nota de redacción del mensuario- destacando el pukara de Turi, el de Lasana, los pueblos de Ayquina, Caspana, Peine, entre otros (Montandon, 1949, No 193; $\left.N^{\circ} 194 ; 1950, N^{\circ} 195\right)$.

Gracias a Roberto Montandon se restauró el pukara de Lasana -dirigido por él en 1949y sus informes de 1951 sirvieron para declarar Monumentos Nacionales, el campanario de Toconao, la iglesia de San Pedro de Atacama, la de San Francisco de Chiuchiu, la iglesia y campanario de Caspana y las ruinas de la capilla de Misiones de Peine Viejo, por DS 5058 de 6 de julio (Montandon, 1950, 1951).

El desvelamiento del Norte Grande animó a otros colaboradores, como Jean Arondeau que centró sus observaciones en la Pampa del Tamarugal (Arondeau,1948: No 178), mientras H. Sotomayor recordaba los préstamos lingüísticos procedentes del quechua en el norte (Sotomayor, 1948, № 177) y Jorge Varas Sasso hizo una semblanza del avance urbano y hotelero de Antofagasta, resaltando el temple de sus gentes: "Hoy ostenta cómodos hoteles, elegantes residencias particulares, lujosas casas comerciales y algunos buenos edificios públicos... Las playas de los alrededores de Antofagasta son bellas y rocosas. Sobresale en ellas la famosa "Portada", al norte, frente al aeropuerto" (Varas Sasso, 1948, No 178; L.C.C., 1958, No 297). 
Varas Sasso, también, atendió al puerto de Iquique y visualizó en la cantidad de vestigios del pretérito salitrero de Iquique, diversos "escenarios" del ciclo salitrero para el visitante (Varas Sasso, 1952, No 225).

Lo prefigurado por Montandon motivó a otros escritores para ahondar en las cualidades turísticas de las urbes costeras. Iquique le fue reconocida en 1948 sus magníficas playas, no olvidando los colaboradores de trazar un itinerario entre la capital provincial y las aguas termales de Pica y Mamiña. Así se comenzaba a conformar una conectividad de lugares con distintos fines (Albornoz, 1948, No 177; Agacino, 1954, No 247; R.A.A., 1954, N²47). En Arica, observaba una colaboradora, el mestizaje demográfico daba personalidad al lugar, comunicando la vida de los valles con la costera (Illanes, 1954, $N^{\circ}$ 254). Y dentro de esos valles destacaba el de Azapa, casi con un paisaje similar al valle Jordán (Varas, 1952, № 223). Un atractivo que no escapó de ser vinculado con una fecha de relevancia para los viajes, era la festividad de La Tirana. Se hizo notar que en 1952 habían concurrido 14.000 personas a su Santuario, haciendo realidad dicha peregrinación por las facilidades brindadas por el FF.CC. del Estado que disponía anualmente de un servicio especial de trenes (En Viaje, 1953, N²37).

Si lo que se ponderaba en Tarapacá, era el transitar de blancos e indígenas junto a mestizos, en Calama, anotaba Bermúdez Miral, los avances modernizantes llevados a cabo desde el municipio iban rezagando el "fondo autóctono del aire indígena y multicolor" (Bermúdez Miral, 1958, № 297).

La importancia social de los lugares urbanos, discurrió de la mano de los breves apuntes historiográficos que Óscar Bermúdez Miral -el gran historiador del salitre, a partir de 1963- va a redactar para la revista. Iquique se asomaba como romántico y nostálgico: "En esta ciudad, como en pocas otras, se siente en todas partes la presencia de lo viejo... del pasado regional", anotaba en su artículo Iquique, espejo del recuerdo. Taltal, luchaba para no caer en el olvido, mientras Antofagasta y Tocopilla "se alzan como expresiones de voluntad vital y de permanente esperanza de progreso" (Bermúdez, 1959,
№ 305; 1958, No 295; Letelier del Campo, 1952). Otros apuntaron a relacionar Iquique con su pasado glorioso de la industria del salitre o más cercanamente con los triunfos de récords mundiales en pesca deportiva de alta mar o con los campeones de boxeo que había aportado (González, 1952: № 237; Escudero, 1952, No 237). Un oriundo de Taltal, el escritor Sady Zañartu, volvía a descubrir la destreza de los pescadores de su localidad, la vida apacible que pertenece a "los pueblos antiguos, de tradición social y política como Taltal" y la esperanza en la Hostería que se construía por el Consorcio Hotelero de Chile (Zañartu, 1959, № 303).

Los años 1945 y 1959 posibilitaron a la revista En Viaje rectificar el olvido y avanzar decididamente de las anotaciones de Montandon hacia el rescate del Norte Grande. La geografía del desierto abría su espectro de paisajes ocultos.

\section{En Viaje y la institucionalización del turismo de la naturaleza y del paisaje urbano nortino}

Este cúmulo de anotaciones y agudas observaciones fundamentaron la creación de un atractivo turístico especial del Norte Grande. Para la revista En Viaje, la región septentrional no solamente ofrecía "escenarios" turísticos sino que brindaba diversos insumos para llevar a cabo una "acción turística" estacional: en invierno. Se lee, de mano de su director Manuel Jofré:

"Si el Sur de Chile ofrece al turista la belleza incomparable de sus bosques y sus lagos, si la Zona Central le muestra la fertilidad de sus campos, la belleza de sus balnearios, el adelanto de sus ciudades, la Zona Norte no deja de brindarle atractivos de innegable valor turístico, como son la pesca en alta mar, sus termas, sus vestigios arqueológicos, sus imponentes yacimientos minerales con características únicas en el mundo, su folklore de atrayente colorido, sus excelentes productos vitícolas, como pajarete y pisco, su variedad de peces y mariscos, sus frutos de tipo tropical, en las que se distingue el 
mango y la guayaba y, principalmente, el clima primaveral de sus puertos, en los que no se conoce el invierno"(En Viaje,1954, $\mathrm{N}^{\circ}$ 247).

Si bien se colocaba en la misma geografía a La Serena, el Elqui con Arica, Azapa, se podía inferir el contraste de la oferta de escenarios e insumos turísticos que se le asignaba al Norte Grande. E incluso, se mentaba las ventajas del FF.CC. de Antofagasta a Salta para el turismo trasandino, además de Bolivia y Perú, por el momento de gran acercamiento que existía entre los gobiernos de Santiago y La Paz (González Pizarro, 2002b). Al mes siguiente, junio de 1954, la revista regaló una estampa nortina en su portada: tocador de "zampoña" en Socoroma. El editorial en comento fue importante pues ese mismo año, en diciembre, se celebró en Puerto Varas el Primer Congreso Nacional de Turismo, donde se debatió la estructuración del turismo en regiones (En Viaje, 1954, N²54).

Con este telón de fondo, la revista comenzaba lo que hemos denominado un proceso de la institucionalización del turismo de la naturaleza y del paisaje urbano. En junio de 1960, se podía leer:

"Desde el punto de vista climático, la zona norte presenta mejores aptitudes para excursiones de invierno... la temperatura en el Norte Grande apenas a $15,6^{\circ}$. Clima magnífico, exento de lluvia y tornado, con sol constante y aire tenue. Ha sido precisamente con estas ventajas que el Gobierno y las autoridades turísticas han planificado una cadena, hoy en marcha, de hoteles adecuados en Taltal, Antofagasta, Iquique y Arica. Las ciudades mencionadas tienen para el visitante una variada gama de ofrecimientos: playas, mares propicios para la pesca y deportes náuticos, aguas curativas, oasis pródigos en frutas especiales y citrus únicos. En un desdoblamiento que parecería contradictorio, sin realmente serlo, el norte abre al viajero las puertas de novedades que bien vale la satisfacción de conocer" (En Viaje, 1969, No 320).

El editorial canonizaba el paisaje nortino con sus escenarios y los insumos a ofrecer. Aquello era ya definitivo. El Estado y los pri- vados habían hecho sus apuestas turísticas en base a este catálogo de la naturaleza. No obstante, la llegada del sacerdote jesuita belga Gustave Le Paige en 1955 a San Pedro de Atacama, iba a aportar uno de los elementos más importantes del patrimonio cultural, las huellas de la cultura atacameña. En 1959 dio a publicidad su primer libro con sus hallazgos, estableciendo seguidamente el Museo de San Pedro de Atacama que lo vinculará a la Universidad del Norte. Todo esto atrajo la mirada científica y, por cierto, turística hacia San Pedro de Atacama, que, ahora, además de su iglesia y oasis y el entorno natural e histórico, ofrecía los descubrimientos de Le Paige (Orellana, 1961, N³27).

Bermúdez Miral va a reparar en Iquique en la "Farmacia Danesa" cuyo dueño Ancker Nielsen, se había transformado en un arqueólogo autodidacto notable, colectando interesante material lítico que comenzó a llamar la atención de los científicos (Bermúdez, 1960, $N^{\circ} 328$ ).

Sentar la idea de un paisaje total en el Norte Grande demandaba establecer un pasado histórico-arqueológico relevante para la memoria regional y atractivo para la curiosidad turística. Así, mientras Ferrara Linares hacía notar que Tarapacá la Sierra de Atacama fueron ducados y encomienda en la Colonia (Ferrara Linares,1960, No 323; Bermúdez, 1964, No 327), Gerardo Leñeros Ilamaba la atención hacia los resultados del Plan de Riego comenzado en 1957 para obtener producción agrícola al interior de Iquique (Leñeros, 1962, No 346). Y por cierto se volvía a insistir en las termas de Mamiña, en las cuatro fuentes (Del Villar, 1968: No 365).

En el transcurso del decenio de 1960 vino el reconocimiento definitivo del Norte Grande, en cuanto a las bondades de su paisaje y los escenarios turísticos. Este giro estuvo unido a las fuertes demandas regionales, canalizadas por los organismos ciudadanos que hemos mencionado en líneas superiores y por el apoyo estatal en pro de beneficios o franquicias industriales, agropecuarias y comerciales, desde Arica hasta Antofagasta. La asistencia fiscal fue decisiva en esta década a través de CORFO Norte y la continuidad de la red hotelera. 
La revista En Viaje asumió la estandarización de los insumos y escenarios turísticos en el marco de su apuesta por la recreación invernal donde el Norte Grande se transformaba en geografía del ocio y del descanso y, en tal encuadre destinó dos números especiales tanto para Tarapacá como de Antofagasta. En lo concerniente a la provincia de Tarapacá, afirma:

"Impulsos provenientes de la acción gubernativa y del aporte particular están canalizando sus fuerzas para que Tarapacá logre el resurgimiento económico que justificadamente pide y espera... Sus recursos son múltiples. El turismo es otro de los puntos de apoyo en el plan de establecimiento de su vida económica. Al clima ideal de la zona se debe sumar el valor curativo de sus termas y la regocijante emoción de sus playas. Arica, Pisagua, Iquique y la pampa registran en su historia un pasado esplendoroso" (En Viaje, 1960, No 325).

Las palabras del director de la revista hacían referencia a una difusión hacia la comunidad nacional de los lugares y referencias turísticas que los tarapaqueños sabían y gozaban pero también de iniciativas económicas (En Viaje, 1960, № 325; 1960, № 325b).

No escapaba a la publicación las diferencias entre Arica e Iquique. La cabeza de Chile, como la denominó Andrés Sabella, constituía un polo de desarrollo turístico, y no se encontraba en crisis económica como Iquique:

"Arica se está preparando para cumplir la vasta misión turística y de todo orden que ella ha recibido por designios felices como encrucijada de tres países: Chile, Bolivia y Perú. Pronto se levantarán viviendas, unas frente al mar, otras en medio de jardines y prados. Se harán casetas de veraneo, canchas de golf, hipódromo, museo arqueológico regional... Se trata de montar un ambiente turístico no ruidoso ni de derroche, sino algo tranquilo y acogedor. Los intérpretes y guías de turismo tienen con este Morro un abundante material de ilustración para el viajero. El casino aumenta el contingente de los visitantes, en una posición paisajística admirable, próxima al balneario "La Lisera"
(En Viaje, 1960, № 325c; En Viaje, 1961, $\left.N^{\circ} 133\right)$.

En el transcurso del año 1962, Sady Zañartu daba a conocer un nuevo friso sobre la costa nortina y muy especialmente sobre Taltal, rescatando el "rezago de caliche de la "Flor de Chile" o de la oficina Chile-Alemania" con los rincones históricos del puerto y la modernidad simbolizada en la novel hostería (Zañartu, 1962, № 344).

Se recogía de Tocopilla sus flamantes muelles que constituía la modernización de su actividad portuaria y sus dos balnearios y la historia escondida del "Dr. Marcos Macuada y la peste, del dirigente obreril Luis Emilio Recabarren y del pregón libertario "El proletario" (Mella, 1962, № 345).

Héctor Vidal Caballero fijó su atención en la cotidianeidad de los distintos barrios de Iquique, desde "El Colorado" hasta "El Morro" (Vidal, 1962, No 342).

La circunstancia de la conmemoración del centenario del poblamiento de Antofagasta brindó a la revista la ocasión propicia de cerrar esta gradual información del desvelamiento del Norte hasta finalmente incluirla en la agenda turística y brindar el reconocimiento más pleno a su paisaje natural y cultural:

"Ancho es Chile por la parte de su Norte Grande calichero. Dura, la vida, es por esos contornos. El escenario nortino es tal que obliga a un incitante diálogo continuado: el que se desarrolla entre su imponencia y el yo íntimo de sus hombres. Antofagasta, ciudad única, nacida al calor del desierto y de la pujanza de los chilenos, celebra por estos días el centenario de su poblamiento. Genuina representante de nuestro Norte que preside con su urbana estructura, calcando la larga y angosta forma de la patria entera, su pasado la singulariza entre las ciudades chilenas: única que fue fundada por compatriotas; su presente la distingue y dinamiza como centro natural de una región de gravitación importante y creciente en lo universitario, lo minero y lo industrial; el futuro latinoamericano le reserva una posición de privilegio en la 
ineludible integración regional del Cono Sur latinoamericano" (En Viaje, 1966, № 397).

Las figuras antofagastinas más conocidas en los distintos ámbitos fueron convocadas para este número, desde Percy Eaglehurst, las reflexiones regionalistas desde la política del diputado Santiago Gajardo; las emocionadas páginas sobre la urbe y de sus hombres de la pampa de Salvador Reyes y Mario Bahamonde, la nostálgica referencia sobre el Vals de Antofagasta y su creador por Andrés Sabella; el rescate de su primer poblador, Juan López, por Óscar Bermúdez Miral, hasta dar cuenta de las iniciativas del atrapanieblas del investigador Carlos Espinosa de la Universidad del Norte, el prestigio internacional de la arqueología de San Pedro de Atacama Ilevado por el sacerdote Le Paige; los políticos de prestigio en el gobierno de Eduardo Frei Montalva, el embajador Radomiro Tomic, los ministros Edmundo Pérez Zujovic y Juan de Dios Carmona.

Concluía En Viaje, su edición especial de su número 397, íntegramente dedicada a Antofagasta, con una confesión que condensaba la distinta mirada del sureño con la del nortino:

"Trató (En Viaje) de presentar la pujante realidad que vive por estos días el Norte Grande, con su capital, la ahora orgullosamente centenaria ciudad de Antofagasta. A los redactores de la revista -sureños en su mayor parte- les pareció un mundo deslumbrantemente distinto. Si hemos logrado comunicar tal sensación al lector, quiere decir que logramos nuestro objetivo" (En Viaje, 1966, № 397).

\section{Conclusiones}

Las provincias del Norte Grande fueron consideradas durante décadas como mera geografía del desierto, carentes de ofrecer un espacio atractivo en los manuales de geografía y menos en las guías turísticas durante la primera mitad del siglo XX.

La transformación del cambio perceptual provino gradualmente desde la revista En Viaje de la mano del arquitecto suizo Roberto Montandon, quien dio cuenta de otra pers- pectiva de observar la geografía del desierto. Los descubrimientos de valor arquitectónico de los pueblos del interior y de la maravilla cromática que ofrecía el espacio precordiIlerano, dieron cuenta de la existencia de un paisaje nortino que se extendía por los faldeos cordilleranos desde Arica hasta Antofagasta. La pampa calichera no Ilamó la atención de Montandon como tampoco en el tránsito de los años 1945 a 1960, posiblemente porque constituía el espacio del conflicto social que había generado la épica tanto salitrera como proletaria, aun cuando la historiografía marxista y la literatura nortina calichera habían volcado -1944/1951- sus intereses en la arqueología del movimiento social en las oficinas salitreras.

Establecer el canon del paisaje nortino significó obligadamente incorporar los asientos urbanos desde Arica, Iquique y Antofagasta, por cuanto en ellos estaban radicados las fuertes inversiones estatales de la red hotelera y del incentivo turístico. Eran también el punto de partida de la conectividad aérea, marítima y caminera hacia el interior. Solamente el FF.CC estatal atravesaba la depresión intermedia.

Si bien el paisaje nortino en su vertiente natural fue difundido como una estrategia de incentivar el turismo interno, como alternativa al turismo invernal precisamente por su estabilidad climática -el predominio estacional de la primavera-, los descubrimientos arqueológicos de Le Paige en San Pedro de Atacama y la red de museos ad hoc establecidos por las sedes universitarias, abrieron la ventana hacia el paisaje cultural del norte. De este modo, pudieron incorporarse determinadas faenas mineras -principalmente las cupreras- en un itinerario cultural que aunó también el turismo de salud -las aguas termales- logrando en la década de 1960 fijar una guía definida de lugares a ofertar tanto hacia la precordillera como en la costa.

La década de 1960 consagró la incorporación plena del Norte Grande como paisaje nortino y la vez el descubrimiento y difusión turística de sus "escenarios naturales", de la mano de los inicios de un proceso de modernización estatal de la zona norte, mediante la aplicación de leyes de franquicias que favorecieron principalmente a Arica, capital del 
turismo nortino, y en menor medida a Antofagasta e Iquique. Aquella transformación se reflejó en los cambios metodológicos de los libros de enseñanza de geografía nacional, siendo un paradigma el texto de Pedro Cunill.

\section{Referencias bibliográficas}

AGACINO, R. Mamiña, o la niña de mis ojos. En Viaje, 1954, №247, p. 25.

Al encuentro de Antofagasta. En Viaje, 1966, noviembre, № 397.

ALBORNOZ, J. Iquique. En Viaje, 1948, junio, $N^{\circ} 177$.

ALMEYDA, E. Geografía de Chile. Santiago de Chile: Imprenta Casa Nacional del Niño, 1955.

ÁlVAREZ, L. et al. Arica en el tiempo. Reseña fotográfica. Arica: Universidad de Chile, 1980.

ANDRADE, R. Chuquicamata, imágenes en silencio. Calama: Gráfica Latue, 2008.

ARANDA, X. et al. San Pedro de Atacama, elementos diagnósticos para un plan de desarrollo loca. Santiago de Chile: Universidad de Chile, Instituto de Geografía, 1964.

ARCE, I. Narraciones históricas de Antofagasta. Antofagasta: Corporación Pro Antofagasta, 2004.

Arica, Centro de Turismo Internacional. En Viaje, 1960, №325, p. 80-83.

ARONDEAU, J. Por los antiguos y olvidados caminos. En Viaje, 1948, No 178.

Atractivos del Norte. En Viaje, 1961, № 333.

AUGÉ, M. El viaje imposible. El turismo y sus imágenes. Barcelona: Editorial Gedisa, 1998.

BENEDETTI, A. El ferrocarril Huaytiquina, entre el progreso y el fracaso. Aproximaciones desde la geografía histórica del territorio de los Andes. Revista Escuela de Historia, 2005, enero-diciembre, Vol. 1, N4, p. 123-165.
BERMÚDEZ, O. Tocopilla, la ciudad de las piedras fantásticas. En Viaje, 1958, № 295, p.10.

BerMúdeZ, O. Calama, San Pedro de Atacama y Toconao. En Viaje, 1958, № 297, p. $10-11$.

BERMÚDEZ, O. La tristeza de los puertos abandonado. En Viaje, 1959, № 305, p. 32-33.

BERMÚDEZ, O. La vida de Ancker Nielsen en Iquique y su dedicación a la arqueología. En Viaje, 1960, №328, p. 16-17.

BERMÚDEZ, O. Las crónicas coloniales de Tarapacá. En Viaje, 1964, №367, p. 7-8.

BOMAN, E. Antiquités de la région andine de la Republique Argentine et du Désert d'Atacama. Mission Scientifique G.de Créquis-Montfort et E.Sénéchal de la Grange. Paris: Imprimerie Nationale, 1908.

BOOTH, R. El paisaje aquí tiene un encanto fresco y poético. Las bellezas del sur de Chile y la construcción de la nación turística. Revista de Historia Iberoamericana, 2010, Vol. 3, $N^{0} 1$, Disponible en Internet: http:// revistahistoria.universia.cl/pdfs_revistas/articulo_112_1285888012302.pdf

BOOTH, R. Turismo y representación del paisaje. La invención del sur de Chile en la mirada de la Guía del Veraneante (19321962). Nuevo Mundo-Mundos Nuevos, 2008. Disponible en Internet: http://nuevomundo. revues.org/25052

BRAVO, P. Los "enganchados" en la era del salitre. Madrid: Ediciones Lar, 1983.

BRAVO, P. y GONZÁLEZ, S. Iquique y la pampa. Relaciones de corsarios, viajeros e investigadores (1500-1930). Antofagasta: Universidad José Santos Ossa- Taller de Estudios Regionales, 1994.

BRUNET, V. Chili. Sur les traces des mineurs de nitrate. Paris: Documents Amériques latines, L' Harmattan, 2006.

BURGOS, G. Fotografía del Salitre. Provincia de Antofagasta y Departamento de Tocopilla. Santiago de Chile: Ed. Orígenes, 2003. 
BURGOS, G. Vistas de los antiguos puertos salitreros a través de sus postales de época 1898-1930. Santiago de Chile: Ediciones Ricaaventura, 2005.

CANIHUANTE, G. Paisaje y turismo en la formación de la identidad de Chile. Aportes y Transferencias, Universidad Nacional del Plata, 2005, Vol. 1, p.75-92.

CID, G. y SAN FRANCISCO, A. (Editores). Nación y nacionalismo en Chile. Siglo XIX. Santiago de Chile: Ediciones Centro de Estudios Bicentenario, 2009, 2 volúmenes.

CORDERO, L. Historia gráfica del puerto de Antofagasta, abril 1919 - agosto 1929. Santiago de Chile: Graficandes, 2010.

CRISTI, R. y RUIZ-TAGLE, P. La República en Chile. Teoría y práctica del constitucionalismo republicano. Santiago de Chile: Editorial LOM, 2006.

CUNIL, P. Geografía de Chile: nuevo texto para la enseñanza secundaria. Conforme a programas oficiales. Santiago de Chile: Editorial Universitaria, 1963.

DA CUNHA, N. Montevideo. Ciudad balneario (1900-1950). El municipio y el fomento del turismo. Montevideo: Universidad de la República, 2010.

DA CUNHA, N. y CAMPODÓNICO, R. Aportes al estudio comparativo del turismo en el cono sur (1900-1930). Revista América Latina en la Historia Económica, 2005, № 24, p. 39-60.

DEL VILLAR, M. La niña de mis ojos llamaban los Incas a Mamiña. En Viaje, 1968, marzo, $N^{\circ} 365$.

DÍAZ, A.; DíAZ, A. y PIZARRO, E. Arica, Siglo XX. Historia y Sociedad en el extremo norte de Chile. Arica: Ediciones Universidad de Tarapacá, 2010.

El Primer Congreso Nacional de Turismo. En Viaje, 1954, diciembre, № 254.

ESCUDERO, E. Iquique, emporio de récords mundiales de pesca deportiva de alta mar. En Viaje, 1952, julio, № 237.
Espíritu progresista de Tarapacá. En Viaje, $1960, N^{\circ} 325 \mathrm{c}$.

FERRARA, F. Tarapacá y la Sierra de Atacama fueron ducado y encomienda. En Viaje, 1960, No 323, p. 42-43.

Ferrocarriles vencedores del desierto y la montaña. En Viaje, 1960, №325, p. 84-86.

FLORES, E. La enseñanza de la geografía en Chile. Río de Janeiro: Instituto Panamericano de Geografía e Historia, Publicacao N ${ }^{\circ}$ 217, 1958.

FRÍAS, F. Geografía General. Educación Media. De acuerdo con la reforma educacional. Santiago de Chile: Editorial Nascimento, 1970.

FRÍAS, F. Manual de Geografía de Chile. Santiago de Chile: Editorial Nascimento, 1960-1966.

GALDAMES, L.; RÍOS, W.; DAUELSBERG, P.; CHACÓN, S. y ÁlVAREZ, L. Historia de Arica. Arica: Ilustre Municipalidad de Arica, 1981.

GALENO, C. Hotel Turismo de Antofagasta, 1950-1953. Revista AOA, Asociación de Oficinas de Arquitectura, 2008, p. 38-43.

GARCÉS, E. Las ciudades del salitre. Santiago de Chile: Editorial Orígenes, 1999.

GÓMEZ, J. El paisaje integrado de las montañas andaluzas. Análisis de la metodología experimentada. Cuadernos Geográficos, 2000, No30, 445-467.

GÓMEZ, A. La evolución internacional de la Geografía del Ocio. Geocrítica. Cuadernos Críticos de Geografía Humana, 1987, Año XII, N 69. Disponible en internet: http:// www.ub.edu./geocrit./ciencbil/htm

GÓNGORA, M. Ensayo histórico sobre la noción de Estado en Chile en los siglos XIX y $X X$. Santiago de Chile: Editorial Universitaria, 2006.

GONZÁLEZ, J. Primeros levantamientos cartográficos generales de Chile con base científica. Los mapas de Claudio Gay y Ama- 
do Pissis. Revista Geográfica Norte Grande, 2007, Vol. 38, p. 21-44.

GONZÁLEZ, S. y PEREIRA H. Iquique Puerto Mayor. Historia iconográfica desde sus orígenes hasta nuestros días. Iquique: Editorial Mallku, 1995.

GONZÁLEZ, S. Hombres y mujeres de la Pampa. Tarapacá en el ciclo de expansión del salitre. Santiago de Chile: LOM-Centro de Investigaciones Diego Barros Arana, 2002.

GONZÁLEZ PIZARRO, J. Breve bosquejo de la pampa y del hombre nortino en la literatura chilena. Anales de Literatura Hispanoamericana, 1983, № 12, p. 81-97.

GONZÁLEZ PIZARRO, J. Chile y Bolivia entre 1930-1955. Notas sobre las relaciones desde la perspectiva del Norte Grande chileno. Si Somos Americanos, 2002a, Año 2, Vol. III, p.13-32.

GONZÁLEZ PIZARRO, J. Espacio y política en Antofagasta en el ciclo salitrero. La percepción del desierto y el sentimiento regionalista, 1880-1930. En: CONTI, V. y LAGOS, M. Una tierra y tres naciones. El litoral salitrero entre 1830 y 1930 . Jujuy: Universidad Nacional de Jujuy, 2002b, p. 251-290.

GONZÁLEZ PIZARRO, J. La pampa salitrera en Antofagasta. La vida cotidiana durante los ciclos Shanks y Guggenheim en el desierto de Atacama. Santiago de Chile: Corporación Pro Antofagasta, 2003.

GONZÁLEZ PIZARRO, J. La imagen de Chile en la obra inédita y desconocida de Andrés Sabella (1912-1989). Historia, 2007, Vol. $40, \mathrm{~N}^{\circ} \mathrm{I}$, p. 35-68.

GONZÁLEZ PIZARRO, J. La conquista de una frontera. Mentalidades y tecnologías en las vías de comunicación en el desierto de Atacama. Revista de Geografía Norte Grande, 2008, No 40, p. 23-46.

GONZÁLEZ PIZARRO, J. El conocimiento del territorio por viajeros y exploradores. En: LLAGOSTERA, A. et al. Región de Antofagasta. Pasado, Presente y Futuro. En el Bicentenario de Chile 1810-2010. Santiago de Chile: Morgan Impresores - Gobierno de Chile, Go- bierno Regional de Antofagasta- Universidad Católica del Norte, 2009a, p. 83-93.

GONZÁLEZ PIZARRO, J. Imaginarios contrapuestos. El desierto de Atacama percibido desde la región y mirado desde la nación. Revista Dialectología y Tradiciones Populares. Antropología. Etnografía. Folklore, 2009b, Vol. LXIV, N² 2, p. 91-116.

GONZÁLEZ PIZARRO, J. Patrimonio, museos y arqueología. De la visibilidad de los pueblos indígenas a la institucionalización de los estudios arqueológicos en el Norte Grande de Chile. Revista Diálogo Andino, 2010a, $N^{\circ} 36$.

GONZÁLEZ PIZARRO, J. La provincia de Antofagasta. Creación y consolidación de un territorio nuevo en el Estado chileno: 18881933. Revista de Indias, 2010b, Vol. LXX, N 249 , p. 345-380.

GONZÁlEZ PIZARRO, J. El puerto fiscal y la ciudad de Antofagasta. En: CORDERO, L. Historia Gráfica del puerto de Antofagasta, abril 1919-agosto 1929. Santiago de Chile: Impresión Graficandes, 2010c, p. 9-27.

GONZÁLEZ PIZARRO, J. Conflictividad y crisis del sistema Shanks y despoblamiento de la pampa nitrosa en la provincia de Antofagasta: 1950-1966. La fiscalización municipalparlamentaria. Revista de Ciencias Sociales, 2011, No 26, p. 7-23.

GONZÁLEZ, A. Iquique y la industria salitrera. En Viaje, 1952, julio, № 237, p. 21.

Guía Oficial de la Exposición y Feria de Industria, Arte y Comercio, 21 de julio de 1934. Antofagasta: Imprenta Skarnic, 1934.

GUZMÁN, N. Autorretrato de Chile. Santiago de Chile: Editorial Zig-Zag, 1966.

HANSON, E. Out-of-the-World Villages of Atacama. Geographical Review, 1926, Vol. 16, No 3, p. 365- 377.

HIERNAUX-NICOLÁS, D. Turismo e imaginarios. En: HIERNAUX-NICOLÁS, D.; CORDERO, A. y VAN DUYNEN MONTIJO, L. Imaginarios sociales y turismo sostenible. Costa 
Rica: Cuadernos de Ciencias Sociales 123, FLACSO, 2002.

Historia de "La Tirana". Su Santuario en la Pampa del Tamarugal. En Viaje, 1953, N²37, p. 25-27.

ILLANES, G. Embeleso de Arica. En Viaje, $1954, N^{\circ} 254$, p. 44-45.

LLOYD, R. Impresiones de la República de Chile en el Siglo Veinte. Historia, Gente, Comercio, Industria y Riqueza. Londres: Artistas Impresores, 1915.

Iquique, gran emporio pesquero. En Viaje, $1960, N^{\circ} 325 b$, p. 78-79.

JOFRÉ, M. Antofagasta: terminal FF.CC. Internacionales. En Viaje, 1966, №397, p. 17.

JOFRÉ, M. El Norte, centro de turismo invernal. En Viaje, 1954, Nº 247.

KAPLAN, O. Geografía de Chile. Barcelona: Imprime Manuel Pareja, 1970

L.C.C. Antofagasta. En Viaje, 1958, Nº 297, p. 13-14.

LAGUNAS, D. El espacio del turismo. A/teridades, 2006, Vol. 16, Nº 31, p. 119-129.

LARRAIN, J. Identidad chilena. Santiago de Chile: Ediciones Lom, 2001.

LEÑEROS, G. Cultivos de frutas y verduras en salares del Norte Grande. En Viaje, 1962, № 346.

LETELIER DEL CAMPO, M. Recuerdos del Norte. En Viaje, 1952, N²19, p. 65-66.

LOIS, C. Del desierto ignoto a territorio representado. Cartografía, Estado y Territorio en el Gran Chaco Argentino (1866-1916). Cuadernos de Territorios, 2002, Nº 10.

Manual del viajero. Baedeker de la República de Chile publicado por la Sociedad Editora Internacional. Santiago de Chile: Imprenta y Litografía América, 1910.

MAYA, O. El Norte Grande chileno en la narrativa. Panorama de Literatura Regional. Antofagasta: Emelnor Impresiones, 2005.
MELLA VALDÉS, T. Tocopilla. Escenario de epopeyas de Macuada y Recabarren. En Viaje, 1962, julio, $N^{\circ} 345$.

Memorial elevado a la Honorable Comisión de Hacienda de la Cámara de Diputados por la Comisión del Norte sobre el proyecto salitrero presentado por el Ejecutivo, 2 de agosto de 1933. Santiago de Chile: Imprenta Wilson, 1933.

MIRANDA, G. La participación del turismo en la modificación del paisaje cultural de Malinalco, Estado de México. Pasos. Revista de Turismo y Patrimonio Cultural, 2006, Vol. 4, No 2, p. 201-211.

MONTANDON, R. Por los monumentos nacionales. En Viaje, 1948, N 182 , p. 50-51.

MONTANDON, R. Apuntes sobre el Pukará de Lasana. Santiago de Chile: Serie de Cuadernos del Consejo de Monumentos Nacionales, 1950, $\mathrm{N}^{\circ} 1$.

MONTANDON, R. Arica, bifurcación internacional. En Viaje, 1948, Nº 180.

MONTANDON, R. Colores y latitudes. En Viaje, 1948, N¹79, p. 68-69.

MONTANDON, R. Iglesias y Capillas Coloniales en el Desierto de Atacama. Santiago de Chile: Serie de Cuadernos del Consejo de Monumentos Nacionales, 1951, Nº 2.

MONTANDON, R. La quebrada de Tarapacá. En Viaje, 1949, N 191, p. 74-75.

MONTANDON, R. Oasis en el desierto de Atacama. I. En Viaje, 1948, № 175, p. 37-38.

MONTANDON, R. Oasis en el desierto de Atacama. II. En Viaje, 1948, No 178, p. 42-43.

MONTANDON, R. Por la ruta del Gran Salar de Atacama. En Viaje, 1948, Nº 181, p. 50-51.

MONTANDON, R. Pueblos y fortalezas preincaicas en el Desierto de Atacama. En Viaje, 1949, No 193, p. 50-51; 1949, No 194, p. $68-69 ; 1950, \mathrm{~N}^{\circ} 195$, p. 54-55.

MONTANDON, R. Reliquias Históricas de Chile. En Viaje, 1945, N 139, p. 48-50. 
MONTANDON, R. Reportaje a la "Tierra de Nadie. En Viaje, 1950, N²04, p. 52-54.

MONTANDON, R. Tocopilla. En Viaje, 1948, N 174, p. 43-44.

MORETIC, Y. El relato de la pampa salitrera. Santiago de Chile: Ediciones del Litoral, 1962.

NAVARRO, P. (Compilador), Patagonia, Ciencia y Conquista. La mirada de la primera comunidad científica argentina. Comahue: Centro de Estudios Patagónicos. Facultad de Ciencia de la Educación, 2005.

NAVARRO, P. La Patagonia en los primeros textos escolares argentinos (1870-1877). Anuario de Historia de la Educación, № 32 (2000-2001), p. 139-152.

NAVARRO, P. y VEJSBERG, L. El proyecto turístico baricholense antes de Bustillo: entre la prehistoria del Parque Nacional Nahuel Huapi y el desarrollo local. Estudios y Perspectivas de Turismo, 2009, Vol.18, $\mathrm{N}^{\circ} 4$, p. 414-433.

NúÑEZ, L. Las investigaciones de Friedrich Max Uhle en el desierto de Atacama (norte de Chile). En: KAULICKE, P.; FISCHER, M.; MASSO, P. y WOLFF. G. Max Uhle (1856-1944). Evaluaciones de sus investigaciones y obras. Lima: Fondo Editorial de la Pontificia Universidad Católica del Perú, 2010, p. 337-348.

NúÑEZ, L. Conflicto y cultura en los oasis de San Pedro de Atacama. Santiago de Chile: Editorial Universitaria, 1992.

NUÑEZ, P. y VEJSBERG, L. El turismo, entre la actividad económica y el derecho social. El Parque Nacional Nahuel Huapi, Argentina, 1934-1955. Estudios y Perspectivas de Turismo, 2010, Vol. 19, № 6.

ORELLANA, R. M. Descubrimientos arqueológicos en el Norte de Chile. En Viaje, 1961, No327, p. 24-25.

PANADÉS, J. y GONZÁLEZ PIZARRO, J. Antofagasta, historia de mi ciudad. Antofagasta: Corporación Pro Antofagasta, 1998.
PÉREZ, L. Elementos de geografía: nociones de la geografía de Chile y de América. Santiago de Chile: Imprenta y Litografía Universo, 1931-1958.

PIGLIA, M. El despertar del turismo: primeros ensayos de una política turística en la Argentina (1930-1943). Journal of Tourism History, Disponible en Internet: http://historiapolitica.com/datos/bilbioteca/piglia.2pdf.

PINTO, J. Estudio preliminar: La Historia y la Causa. En: RAMÍREZ, H. Obras escogidas Volumen I. Balmaceda y la contrarrevolución de 1891. Historia del Movimiento obrero en Chile. Santiago de Chile: LOM Ediciones, 2007.

Proyecciones turísticas del Norte. En Viaje, 1969, N³20.

R.A.A. Pica, flor del desierto. En Viaje, $1954, N^{\circ} 247$, p.37.

RECABARREN, F. et al. Antofagasta, historia en imágenes. Santiago de Chile: Editorial Universitaria- Universidad de Chile, 1979.

REYES, S. Andanzas por el desierto de Atacama. Santiago de Chile: Editorial ZigZag, 1969.

ROJAS, M. El Imaginario. Civilización y cultura del siglo XXI. Buenos Aires: Prometeo Libros, 2006.

SABELLA, A. Norte Grande. Novela del Salitre. Santiago de Chile: Ediciones Orbe, 1944.

SABELLA, A. Semblanza del Norte Chile. Santiago de Chile: Editorial Universitaria, 1955.

SALAZAR, G. y PINTO, J. Historia contemporánea de Chile. Vol.I. Estado, legitimidad, ciudadanía. Santiago de Chile: LOM Ediciones, 1999.

SANTORO, C. et al. El legado de Max Uhle en la arqueología de Arica. En: KAULICKE, P.; FISCHER, M.; MASSO, P. y WOLFF. G. Max Uhle (1856-1944). Evaluaciones de sus investigaciones y obras. Lima: Fondo Editorial de la Pontificia Universidad Católica del Perú, 2010, p. 349-358. 
SCARZARELLA, E. El ocio peronista: vacaciones y turismo popular en Argentina (19431955). Entrepasados, 1998, № 14, p. 65-86.

SCARZARELLA, E. Las bellezas naturales y la nación: los parques nacionales en Argentina en la primera mitad del siglo XX. Revista Europea de Estudios Latinoamericanos y del Caribe, 73, 2002, p. 5-21.

SCHULTER, S. How To See Colorado: The Federal Writer's Projetc, American Regionalism, and the Old New Western History. Western Historical Quarterly, 2005, №36, p. 49-70.

SHEFFER, M. See America First. Tourism and National Identity, 1880-1940. Washington: Smithsonian Institute Press, 2001.

SILVA NARRO, D. Guía administrativa, industrial y comercial de las provincias de Tarapacá y Antofagasta. Santiago de Chile: Imprenta Universitaria, 1892- 1919.

SILVESTRE, G. Postales Argentinas. La Argentina en el siglo XX. Buenos Aires: Ariel -Universidad Nacional de Quilmes, 1999.

SMITH, A. Nacionalismo e indigenismo: la búsqueda de un pasado auténtico. Estudios Interdisciplinarios de América Latina y el Caribe, EIAL., 1990, Vol. I, Nº 2. Disponible en Internet: http://www.tav.ac.il/eial//-2/index. html.\#articulos.

SMITH, A. Nacionalismo. Madrid: Alianza Editorial, 2004.

SOTOMAYOR, H. Chilenismos de origen aimara. En Viaje, 1948, N 177.

SUBERCASEAUX, B. Chile, o una loca geografía. Santiago de Chile: Editorial Ercilla, 1949.

SZIGETHY T. El Ferrocarril de Salta a Antofagasta y su importancia. En Viaje, 1948, № 172.

THOMSON, I. La Red Norte: la historia de los ferrocarriles del norte chileno. Santiago de Chile: Imprenta Silva, 2003.

TRONCOSO, C. y LOIS, C. Política turística y peronismo. Los atractivos turísticos promocionados en Visión de Argentina (1950).
Pasos. Revista de Turismo y Patrimonio Cultural, 2004, Vol. 2, p. 281-294.

URRY, J. La globalización de la mirada del turista. Sobre turistas y turismo. Metrópolis. Revista de Información y pensamiento urbanos, 2008. Disponible en Internet: www.barcelonametropolis.cat/es/pag.asp? id=1.

URRY, J. La mirada del turista. Lima: Escuela Profesional de Turismo y Hotelería, Universidad San Martín de Porres, 2004.

URZÚA L. Arica, puerta nueva. Historia y Folklore. Santiago de Chile: Editorial Andrés Bello, 1957.

VALENZUELA, J. Álbum zona norte. Informaciones salitreras, agrícolas y comerciales. Santiago de Chile: Imprenta Universitaria, 1927.

Valores de pasajes sencillos en trenes expresos, ordinarios y mixtos, entre las principales estaciones de Santiago a Calera, Iquique y ramales. En Viaje, 1966, №388.

VARAS, J. Antofagasta, capital del desierto. En Viaje, 1948, № 178, p. 44-46.

VARAS, J. Los valles de Azapa y Lluta. En Viaje, 1952, N²23, p. 46-47.

VARAS, J. Perfiles y colorido de Iquique. En Viaje, 1952, $\mathrm{N}^{\circ} 225$, p. 66-67.

VÁSQUEZ, J. Arica, puerto del tiempo. Arica: Oñate impresores, 2002.

VÁSQUEZ. J. Historia de salitre y mar. Iquique y la pampa. Iquique: Universidad Arturo Prat, 1997.

VERA, F. Análisis territorial del turismo. Barcelona: Ediciones Ariel, 1997.

VIDAL CABALLERO, H. La mañana iquiqueña. En Viaje, 1962, Nº 347.

Visión de Tarapacá. En Viaje, 1960, № 325 .

ZAÑARTU S. Por la costa nortina. En Viaje, 1962, No344, p. 6-7.

ZAÑARTU, S. Taltal a todo fondo. En Viaje, 1959, No 303, p. 24-25. 